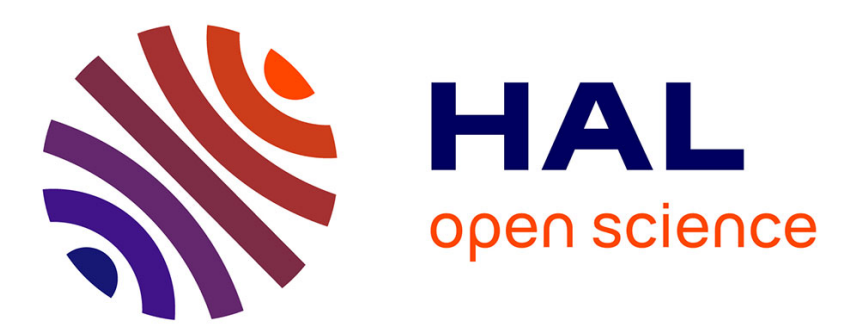

\title{
A method for estimating the migration time of plant species within the time range of $14 \mathrm{C}$-Dating
}

Etienne Juvigné, Georgette Delibrias, Bruno Bastin, Jacques Evin, Maurice Streel

\section{- To cite this version:}

Etienne Juvigné, Georgette Delibrias, Bruno Bastin, Jacques Evin, Maurice Streel. A method for estimating the migration time of plant species within the time range of 14C-Dating. Quaternary International, 1998, 47-48, pp.147-152. 10.1016/S1040-6182(97)00081-5 . hal-03119653

\section{HAL Id: hal-03119653 https://hal.science/hal-03119653}

Submitted on 2 Nov 2021

HAL is a multi-disciplinary open access archive for the deposit and dissemination of scientific research documents, whether they are published or not. The documents may come from teaching and research institutions in France or abroad, or from public or private research centers.
L'archive ouverte pluridisciplinaire HAL, est destinée au dépôt et à la diffusion de documents scientifiques de niveau recherche, publiés ou non, émanant des établissements d'enseignement et de recherche français ou étrangers, des laboratoires publics ou privés. 


\section{A METHOD TO ESTIMATE THE MIGRATION TIME OF PLANT SPECIES WITHIN THE TIME RANGE OF ${ }^{14} \mathrm{C}$-DATING}

Etienne Juvigné *, Bruno Bastin**, Georgette Delibrias***, Jacques Evin**** and Maurice Streel*****

* National Fund for Scientific Research (Belgium), ULg.: Laboratory of Geomorphology and Quaternary Geology, 7, Place du XX Août, B 4000 Liège, Belgium

** UCL, Laboratory of Palynology and Dendrochronology, Place Croix du Sud, 4-5, B 1348 Louvain-la-Neuve, Belgium

*** Centre des Faibles Radioactivités, F 91198 Gif sur Yvette, Cedex, France

**** C. Bernard University, Laboratory of Radiocarbon LA CNRS 11, F 69622 Villeurbanne, Cedex, France ***** University of Liège, Laboratories of Paleontology, 7, Place du XX Août, B 4000 Liège, Belgium.

Two hundred and fifty ${ }^{14} \mathrm{C}$ dates available in the French Massif Central, in Germany and in High Belgium are discussed in a way different from that previously. It is shown that in an area of the French Massif Central as small as $100 \times 100 \mathrm{~km}$, Holocene pollen features in pollen diagrams are biostratigraphic tools delineating time ranges of several centuries. Larger time ranges characterize the early Holocene warming (Quercus, Corylus), and shorter ones, the middle Holocene (Tilia, Fagus). The method of calculation described in this paper can be applied in any area.

\section{INTRODUCTION}

In the Eifel (Germany) and the Massif Central (France), peat-bogs have been investigated intensively for the past decades by palynologists and tephrostratigraphers. In both areas, palynology was often used as a dominant stratigraphic tool: (i) to develop tephrochronologic models (e.g. Reille et al., 1985; Erlenkeuser et al., 1972); (ii) to reject ${ }^{14} \mathrm{C}$ dates requested to develop tephrostratigrahic and/or palynostratigraphic models (e.g. Pons et al., 1988; Erlenkeuser et al., 1972). Tephro-, palyno-, and chronostratigraphic models of the post-glacial period in the French Massif Central were published (Beaulieu et al., 1987; Beaulieu et al., 1988; Juvigné et al., 1988; Juvigné, 1991). In all of them, pollen features are supposed to be slightly diachronic stratigraphic markers.

This paper deals with a overall approach of $250{ }^{14} \mathrm{C}$ dates which have been published in various papers. Since it has been shown that AMS and 'traditional' ${ }^{14} \mathrm{C}$ dating methods give slightly different ages while dating an isochronous tephra bed (Hajdas et al., 1995), the AMS ${ }^{14} \mathrm{C}$ dates are not consisdered in this paper. Furthermore the 'traditional' ${ }^{14} \mathrm{C}$ dates obtained from paleosols for which reliability is largely uncertain (Delibrias, 1979; Evin, 1992) were also excluded. Finally, the calibration of ${ }^{14} \mathrm{C}$ dates is of no concern to this paper because the goal is not to precisely define the ages of various stratigraphic features, but only to compare data obtained by the same method to delineate time ranges. 


\section{RELIABILITY OF ${ }^{14}$ C-DATING}

\section{Self consistency of ${ }^{14} \mathrm{C}$-dating method}

If no lithostratigraphic or palynological disturbance is noted in a sequence (reworking of material is very rare in peat-bogs, except at the margins), a series of ${ }^{14} \mathrm{C}$ dates should increase in age from the surface downwards. In the different peat-bogs of the French Massif Central and the Eifel, among $250{ }^{14} \mathrm{C}$ dates, only 13 deviate from their own series (i.e. $5.2 \%$ ), as shown by an example in Table 1.

\section{Tephrostratigraphy and ${ }^{14} \mathrm{C}$ dates}

The Laacher See Tephra (Eifel/Germany) is one of the best documented tephra of the postglacial time (Bogaard \& Schmincke, 1985). Concerning its age, nineteen ${ }^{14} \mathrm{C}$ dates were published in various papers; they are shown in Figure 1.

Bogaard (1983) and Bogaard and Schmincke (1985) demonstrated that the eruption of the Laacher See volcano (East Eifel, Germany) lasted only a few days, but the time range corresponding to the difference between extreme ${ }^{14} \mathrm{C}$ dates (\#1 and \#19) is 860 years. The following factors may be responsible for deviations (Evin, 1992): (i) in the case of charcoal, the position of the sample in the branch (center or bark); (ii) the fact that at the moment of the eruption, the relevant wood was still alive, or had been lying for a long time on the soil; (iii) in the case of peat samples containing the tephra, the unequal thickness and volume of peat taken above and below the tephra bed, the different compaction of the peat below and above the tephra, and the variation of the sedimentation rate throughout the dated sample; (iv) the different ${ }^{14} \mathrm{C} /{ }^{12} \mathrm{C}$ ratios present in atmospheric $\mathrm{CO}_{2}$ during the deposition of the material constituting the sample; (v) the admixing of juvenile magmatic $\mathrm{CO}_{2}$ (in volcanic areas); (vi) the fresh water effect; (vii) any uncontrolled pollution of the sample. The above cited factors of deviation can be named 'external factors'. The ${ }^{14} \mathrm{C}$-dating method should be responsible for the remaining deviations, if any.

By discussing the rejection of the individual ${ }^{14} \mathrm{C}$ dates of the Laacher See Tephra at the 1 sigma level (Fig. 1), we can conclude as follows.

3 of the 19 dates of the LST (\#1, \#18, \#19: i.e. 15.7\%) do not overlap the range of the weighed mean $(10,895 \pm 85$ yr B.P.). Since the eruption lasted only a few days, it should be pointed out that at the 1 sigma level: (i) there are only 5 dates $(\# 1, \# 14, \# 17, \# 18$, \#19: :i.e. $26.7 \%$ ) which do not include the median age 10,960 yr B.P. (Tabl. 1); (ii) 8 of the 19 dates of the LST (\#1, \#2, \#5, $\# 6, \# 8, \# 14, \# 18$, \#19: :i.e. $42.1 \%$ ) do not include the precise weighed mean. The mean of the three percentages $(15.7 \% ; 26.7 \% ; 42.1 \%)$ is $28 \%$.

By excluding the ${ }^{14} \mathrm{C}$ dates of charcoal (\#5, \#8, \#11, \#13,\#16,\#18), the same criteria give respectively $20 \%, 40 \%$ and $50 \%$ of rejected dates, i.e. a mean of $37 \%$. The overall mean is roughly one third $(32.4 \%)$. 


\section{PALYNOSTRATIGRAPHY AND CHRONOSTRATIGRAPHY}

\section{Diachronism of pollen features}

Within the Holocene, the continuous tree pollen curves in pollen diagrams of the French Massif Central usually start in the following order: Quercus, Corylus, Ulmus, Tilia, Fraxinus, Fagus and Abies. Nevertheless, it has been pointed out that numerous internal inversions occur (Juvigné et al., 1988). This suggests that the appearance and the development of a tree species in a determined area have been recorded diachronously in different nearby peat-bogs. This can be explained for both statistical and ecological reasons: (i) the starting level of any continuous curve depends on the numbers of pollen grains determined; (ii) the relationships between localization of pioneer tree patches and the recording of relevant pollen features in proximal to distal peat-bogs is difficult to constrain. Numerous papers describe the migration of tree species in mountainous areas (e.g. Beaulieu et al., 1992; Tessier et al., 1993; David, 1993). On the one hand short-term diachronism, up to 3 centuries, was accepted by palynologists in developing a detailed palynochronozonation in the French Massif Central [Beaulieu et al. (1982), Beaulieu et al. (1984), Coûteaux (1984), Beaulieu et al. (1985), Reille et al. (1985), Guenet and Reille (1988), Pons et al. (1988)]. Guenet (1993) pointed out that Fagus should have appeared six centuries later on the Millevaches Plateau than in the nearby Auvergne. On the other hand long-term diachronism -up to 6000 years- was pointed out for the onset of Spruce in Switzerland (Markgraf, 1970).

\section{Subjectivity of palyno-zonations}

Palynologists choose subjectively either a single pollen feature or a combination of several to elaborate their own palyno-zonation. Those features should reflect large scale climatic change. Due to the diachronism of individual pollen features, the limits used in palyno-zonation should also be diachronic. This is supported by examples in both the French Massif Central and the West Eifel (Germany) which show that the most contrasting climatic oscillations of the Late-Glacial were sometimes confused. In other cases, the vegetative response to the complexity of Late Dryas climatic cooling (e.g. Kennett, 1990) should also explain such a confusion. In the same way, a clear separation of chrono- and biozonation was proposed for the Late-Glacial period in Switzerland (Amman and Lotter, 1988).

We have also pointed out wrong interpretations of pollen diagrams evenhough the most contrasted climatic oscillations of the Late-Glacial are concerned.

-In the Massif Central, the same pair of tephras, Godivelle T4 and Godivelle T5 (Juvigné, 1987) were placed either wrongly in the Late Dryas [Reille et al. (1985), Guenet and Reille (1988)] or correctly in the Allerød (Bastin et al., 1990) even at similar locations in the same peat-bogs (Graspet, Chambedaze). 
-In the West Eifel a single tephra ("Tuffsand"; see above) occurring in different peat-bogs was placed either correctly in the Allerød (Straka, 1958, 1960), or wrongly in the Late Dryas (Straka, 1954, 1955, 1961) to the Preboreal (Straka, 1956).

-The Laacher See Tephra was also placed within the Boreal (Juvigné and Bastin, 1982) and within the Older Dryas (see Juvigné et al., 1995).

\section{MIGRATION TIME OF FOUR TREE SPECIES}

Two pairs of typical Holocene pollen features in diagrams of the French Massif Central were chosen for the discussion (Fig. 2A): (i) within the early Holocene, the steeply rising curve for Corylus and the beginning of continuous curve for Quercus; (ii) within the middle Holocene, the beginning of continuous curves for Tilia and the steeply rising curves for Fagus. The total number of ${ }^{14} \mathrm{C}$ dates actually available for those pollen features are represented in Table 2 and Figure 1.

Since the 'external factors' responsible for deviations of ${ }^{14} \mathrm{C}$ dates (see above) should give identical deviations in dating either the Laacher See Tephra or pollen features (as far as peat or gyttja samples are concerned in both cases) the diachronism of the latter can be estimated by considering the time ranges separating each pollen curve, and that of the tephra, for any percentage of rejected dates (Fig. 2B). The individual time ranges for each pollen feature are represented in Figure $2 \mathrm{C}$ to $2 \mathrm{~F}$.

Figure 2 shows that pollen features are stratigraphical tools corresponding to various time ranges. This implies that the essential amount of pollen grains supplied by the relevant tree species were deposited only in the near distance of their source. In the same way, the recording of pollen features in more distal peat-bogs depends on the migration of pioneer tree patches. Figure 2 show that the migration time of the relevant pioneer patches throughout the area are in increasing order: Tilia, Fagus, Corylus, Quercus. Nevertheless, the steeply rising curves of Corylus and Fagus indicate that as soon as their pioneer patches had settled an area, their development was rapid. For any percentage of rejected data, the different time ranges obtained for the four tree species may be linked with the various dynamics of the migration of the relevant trees. Nevertherless, there should be a more important relationship between the duration of the tree migration and the combination of climatic factors triggering the relevant development of the species. A longer duration of the migrations characterized the early Holocene (Quercus, Corylus), and a shorter one, the middle Holocene (Tilia, Fagus). This could be explained by hypothetically larger amplitude of climatic oscillations during the Late Dryas/Holocene warming, than in the middle Holocene. Those time ranges should also be different for various degrees of relief; the investigated area is between $850 \mathrm{~m}$ and $1500 \mathrm{~m}$ a.s.1. 
The main question is now what percentage of ${ }^{14} \mathrm{C}$ dates should be rejected in order to estimate the duration of the diachronism of the individual pollen features? The response to this question is relatively subjective.

On the one hand, the concept of long-term diachronism of tree migrations and the recording of the relevant pollen features could imply that all the ${ }^{14} \mathrm{C}$ dates are acceptable as they stand. In each series of ${ }^{14} \mathrm{C}$ dates, the more ancient one seems to deviate (Tabl. 2; Fig. 2), but they could correspond to localities where earlier tree patches have occurred.

On the other hand, the defenders of low diachronism of pollen features should keep in mind that they completely reject the ${ }^{14} \mathrm{C}$-dating method which is anyway the most important source of chronostratigraphy for post-glacial time.

Since more bracketed dates were used to date pollen features than to date the LST (Table 2 and Appendix 2, column C - column F), a slight overestimation of time ranges for pollen features might be expected. However there is no correlation between the duration of the four tree species and the coresponding averages of time ranges bracketing the calculated dates. In the same way, although the averaged bracketed time ranges are similar for both the 'instantaneous' Laacher See Tephra and the steeply rising curve for Fagus, the latter one is diachronic by about 400 years in comparison the the LST curve.

It has been shown above that the different percentages of unreliable dates might be $28 \%$, $32 \%$ or $37 \%$, depending on the severity of the rejection criteria. To avoid arbitrary overestimation of diachronism for pollen features, it is proposed to consider the highest of the three means, i.e. $37 \%$, to estimate the migration time of pollen features (Fig. 2). The latter value assigns the following migration times throughout the French Massif Central of the chosen trees: (i) within the early Holocene, 650 years for Quercus and 600 years for Corylus; (ii) within the middle Holocene, 150 years for Tilia and 400 years for Fagus.

\section{CONCLUSION}

In spite of the fact that the rejection or the acceptance of ${ }^{14} \mathrm{C}$ dates corresponding to a determined stratigraphic feature is subjective, it is shown that Holocene pollen features of Quercus, Corylus, Tilia and Fagus are biostratigraphic tools which are acceptable within various time ranges of several centuries in the French Massif Central. Larger times ranges characterize the early Holocene, and shorter ones the middle Holocene.

It is suggested that the ${ }^{14} \mathrm{C}$-dating method provides roughly about two third of reliable dates. 'External factors' are responsible for most of the one third of deviating dates. The rejection of about $37 \%$ of the available ${ }^{14} \mathrm{C}$ dates is suggested to estimate the migration time of four tree species in the French Massif Central.

The method described in this paper can be applied to series of ${ }^{14} \mathrm{C}$ dates corresponding to any pollen feature occurring in pollen diagrams of any determined area. The regression curve of 
the Laacher See Tephra can be used as a reference curve in all cases. Only the percentage of rejected data should be slighly reduced if less bracketing dates are used to dates the pollen features.

\section{AKNOWLEDGMENTS}

We are grateful to the Reviewers, to Prof. Dr. H. Erlenkeuser and Prof. Dr. H. Willkomm $\left({ }^{14} \mathrm{C}\right.$ Laboratory, Kiel, Germany) for critical review of our manuscript, and to Carolyn Olson (Soil Conservation Service, US Department of Agriculture, Lincoln, U.S.A.) for correcting the language.

\section{REFERENCES}

Amman, B. and Lotter, A. (1988). Late-Glacial radiocarbon- and palynostratigraphy on the Swiss Plateau. Boreas, 18, 109-126.

Bastin, B., Gewelt, M. and Juvigné, E. (1990). A propos de l'âge et de l'origine des téphras tardiglaciaires T4 et T5 de Godivelle-Nord (Massif Central, France). Ann. Soc. géol. Belg., 113, 165-178.

Beaulieu, J.L. de, Kostenzer, J. and Reich K. (1992). Dynamique forestière holocène dans la vallée de l'Arve (Haute Savoie) et migrations de Abies et Picea dans les Alpes occidentales. Dissertationes Botanicae (Festschrift Zoller), 196, 387-398.

Beaulieu, J.L. de, Pons, A. and Reille, M. (1982). Recherches pollenanalytiques sur l'histoire de la végétation de la bordure nord du Massif du Cantal (Massif Central, France). Pollen et Spores, 24/2, 251-299.

Beaulieu, J.L. de, Pons, A. and Reille, M. (1984). Recherches pollenanalytiques sur l'histoire de la végétation des Monts du Velay, Massif Central, France. Diss. Bot. (Festschrift Max Welten), 72, 45-70.

Beaulieu, J.L. de, Pons, A. and Reille, M. (1985). Recherches pollenanalytiques sur l'histoire tardiglaciaire et holocène de la végétation des Monts d'Aubrac (Massif Central, France). Rev. Palaeobot. Palynol., 44, 37-80.

Beaulieu, J.L. de, Pons, A., and Reille, M. (1987). History of vegetation, climate and human action in the French Massif Central over the last 15,000 years. Symposium on Palaeohydrological changes in the temperate zone in the last 15000 years, Lund, Sweden, Abstracts of lectures and posters, Gaillard, M.-J., ed, 27, 207-210.

Beaulieu, J.L. de, Pons, A., and Reille, M. (1988) Histoire de la flore et de la végétation du Massif Central (France) depuis la fin de la dernière glaciation. Cahiers de Micropaléontologie, 3 (4), 5-36.

Bogaard v.d., P. (1983). Die Eruption des Laacher See Vulkans. Thesis, Ruhr-University Bochum, 348 p., Bochum.

Bogaard v.d., P. and Schmincke, H.-U. (1985). Laacher See tephra: a widespread isochronous late quaternary tephra layer in central and northern Europe. Geol. Soc. Am. Bull., 96, 1554-1571.

Coûteaux, M. (1984). Bilan des recherches pollenanalytiques en Ardèche (France). Bull. Soc. roy. Bot. Belg., 117, 181-186.

David, F. (1993). Altitudinal variation in the response of the vegetation to Late-Glacial climatic events in the northern French Alps. New Phytol, 125: 203-220.

Delibrias, G. (1979). Problèmes liés à la datation des sols fossiles par le carbone 14. Bull. Ass. fr. Et. Quat., 1, $35-42$.

Evin, J. (1992). Les datations par le radiocarbone en géologie et en archéologie. Fiabilité de la méthode selon l'origine des matériaux. Docum. Lab. Géol. Lyon, 122, 99p, 7 fig., 16 tabl.

Guenet, P. (1986). Datation par l'analyse pollinique de l'explosion des volcans du groupe Pavin (Besse-enChandesse, Puy de Dôme, France). 11e Réunion des Sciences de la Terre, Clermont-Ferrand, Société géologique de France (Ed.), Paris, p. 86.

Guenet, P. (1993). Analyses pollenanalytiques en Artense et sur le plateau de Millevaches (Massif Central, France). Palynosciences, 2, 79-107.

Guenet, P. and Reille, M. (1988). Analyse pollinique du lac-tourbière de Chambedaze (Massif Central, France) et datation de l'explosion des plus jeunes volcans d'Auvergne. Bull. Ass. fr. Et. Quat., 36, 175-194.

Hajdas, I., Ivy-Ochs, S., Bonani, G., Lotter, A., Zolitschka, B. and Schluichter C. (1995). Radiocarbon age of the

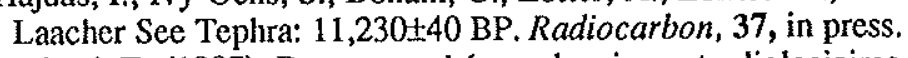

Juvigné, E. (1987). Deux retombées volcaniques tardiglaciaires dans le Cézallier (Massif Central, France). Bull. Ass. fr. Et. Quat., 32, 241-249. 
Juvigné, E. (1991). Spätglaziale und holozăne Tephrostratigraphie im Zentral Massiv (Frankreich). Sonderveröffentlichungen, Geologisches Institut der Üniversität zu Köln, 82 (Festschrift K. Brunnacker), 163174.

Juvigné, E. and Bastin, B. (1982). Découverte d'un tuf volcanique d'âge préboréal à la Grande Pile (Vosges, France). Bull. Soc. géog. Liège, 18, 31-40.

Juvigné, E. and Gilot, E. (1986). Ages et zones de dispersion de téphras émises par les volcans du Montcineyre et du lac Pavin (Massif Central, France). Zeit. deut. geol. Ges., 137, 613-623.

Juvigne, E., Kozarski, S. and Nowaczyk, B. (1994). The occurrence of Laacher See Tephra in Pomerania, NW Poland. Boreas, in press.

Juvigné, E., Milcamps, V., Delibrias, G. and Evin, J. (1988). Ages de traits polliniques et chronozonation du Tardiglaciaire et de l'Holocène dans le Massif Central (France). Med. rijks geol. Dienst, 41/4, 33-50.

Kennetl, J.P. (1990). The younger Dryas cooling event: an introduction. Paleoceanography, 5/6: 891-895.

Long, A. and Rippeteau, B. (1974). Testing contemporaneity and averaging radiocarbon dates. American Antiquity, 39, 205- 215.

Markgraf, V. (1970). Palaeohistory of the Spruce in Switzerland. Nature, 228, 249-251.

Pons, A., Reille, M., Beaulieu, J.L. de, Delibrias, G. and Evin, J. (1988). Relations entre datations ${ }^{14} \mathrm{C}$ et analyse pollinique: l'exemple de l'intervalle 6000-4000 B.P. dans le Massif Central. Bull. Ass. franc. Et. Quat., 1988-1, 35-42.

Reille, M., Beaulieu, J.L. de and Pons, A. (1985). Recherchès pollenanalytiques sur l'histoire tardiglaciaire et holocène de la végétation du Cézallier, de la Planèze de St Flour et de la Margeride. Pollen et Spores, 27/2, 209 270.

Straka, H. (1952). Zur spätquartären Vegetationsgeschichte der Vulkaneifel, Arb. zur rhein. Landeskunde, 1, $116 \mathrm{p}$. Straka, H. (1954). Pollenanalytische Datierung zweier Vulkanausbriche bei Strohn (Eifel). Planta, 43, 461-471.

Straka, H. (1955). Die Auswertung Pollenanalytischer Ergebnisse. Naturwissenschaftliche Rundschau, 8, $480-483$. Straka, H. (1956). Die Pollenanalytische Datierung von jüngeren Vulkanausbrüchen. Erdkunde, 10, $204-216$.

Straka, H. (1958). Ein Spätglaziales Pollendiagramm aus dem Hinkelsmaar bei Manderscheid (Vulkan-Eifel). Flora, $146,412-424$.

Straka, H. (1960). Zwei Pollendiagramme aus dem Hinkelsmaar bei Manderscheid (Vulkaneifel). Decheniana, 112,

219-241.
Straka, H. (1961). Pollenanalytische Untersuchungen spätglazialer Ablagerungen aus zwei Maaren westlich Gillenfeld (Vulkaneifel). Pollen et Spores, 3, 275-302.

Tessier, L., Beaulieu, J.L. de, Coûteaux, M., Edouard, J.L., Ponel P., Rolando, C., Thinon, M., Thomas, A. and Tobolski, K. (1993). Holocene paleoenvironments at the timberline in the French Alps- a multidisciplinary approach. Boreas, 22: 244-254. 


\section{FIGURE CAPTIONS}

Figure 1.- Diagrams for ${ }^{14} \mathrm{C}$ dates obtained for the Laacher See Tephra (Eifel/Germany). Each vertical bar is 1 sigma confidence interval (see data in Table 2).

A, date obtained on peat sample including centered LST bed; B, date calculated by using a pair of dated peat samples bracketing the LST bed (detailed method of calculation is described in legend of Appendix 2); C, date obtained on charcoal contained in proximal pyroclastic products of the volcano. The weighed mean of those 19 dates is $10,895 \pm 85 \mathrm{yr}$ B.P [calculated from the method of Long and Rippeteau (1974), including the Chauvenet's rejection criteria]; the strippled area represents the range of the weighed mean (10810 to $10980 \mathrm{yr}$ B.P.).

Figure 2.- Estimation of diachronism for four typical pollen features of the French Massif Central. A.- Chosen pollen features: FAGUS, middle part of the steep rising curve for Fagus; TLIA, $2 \%$ level for the beginning continuous curve for Tilia; CORYLUS, middle part of the steeply rising curve for Corylus; QUERCUS, $2 \%$ level of the beginning continuous curve for Quercus. The pollen features are placed in respect to their stratigraphic order; the length of the cores (depth) is generally from 2 to $10 \mathrm{~m}$.

B to F.- All abscissa correspond to percentage of rejected successive pairs of extreme dates of each series. All ordinates are years.

B. Regression curves were obtained according to values represented in Table 2: (i) ordinate, remaining time ranges between residual dates after rejecting successive pairs of extreme values (columns C, G, K, O, S); (ii) abscissa, percentages of rejected dates (columns D, H, L, P, T). Rsquarred of regression curves are: Laacher See Tephra, $\mathrm{r}^{2}=0.997$; Fagus, $\mathrm{r}^{2}=0.962$; Tilia, $\mathrm{r}^{2}=0.989 ;$ Corylus, $\mathrm{r}^{2}=0.983 ;$ Quercus, $\mathrm{r}^{2}=0.965$.

$\mathrm{C}$ to F. Estimation of diachronism for four typical pollen features. Each curve represents the time range comprised between the LST curve and the relevant pollen curve in Figure 2B. The triangles indicate that the percentage of rejected data should be comprised between $15 \%$ and $50 \%$, and more likely $37 \%$. 


\section{TABLE CAPTIONS}

Table 1.- ${ }^{14} \mathrm{C}$ dates of the Late-Glacial to Holocene sequence at Le Suc 2 (French Massif Central). The succession of data is in agreement with the stratigraphic position of the samples from top (\#1) to bottom (\#9). Column A, reference to literature; Col. B, locality where the core was taken; Col. C, ${ }^{14} \mathrm{C}$ dates; Col. D, standard errors; Col. E, laboratory labels; Col. F, 'Rejected' as considered with adjacent ${ }^{14} \mathrm{C}$ dates.

This table is a part of another one containing $197{ }^{14} \mathrm{C}$ dates from localities of the French Massif Central, and 54 dates from the Eifel and the nearby High Belgium.

The complete Table 1 can be obtained from E. Juvigné.

Table $2 .{ }^{14} \mathrm{C}$ dates obtained for the Laacher See Tephra and four typical pollen features of diagrams in a $100 \times 100 \mathrm{~km}$ large area of the French Massif Central [Chaîne des Puys (N) to Aubrac (S), and Artense (W) to Monts du Forez (E)].

Columns A, E, I, M, Q: ${ }^{14} \mathrm{C}$ dates; Col. B, F, J, N, R: standard errors; Col. C, G, K, O, S: residual time ranges obtained by rejecting successive pairs of the extremes values [ex. Col. $\mathrm{C}$, \#1: $860=11500$ (Col. A, \#1)-10640 (Col. A, \#19)]; Col. D, H, L, P, T, numbers of rejected ${ }^{14} \mathrm{C}$ dates in percent, corresponding to the aligned values for residual time ranges [(ex. Col. D, \#2: $10.5=100 * 2 / 19$ ( 2 rejected dates/19 available dates) $]$.

References of individual dates and detailed calculation method are given in a detailed table which can be obtained from E. Juvigné. For the LST, 6 of the 19 dates were calculated by using bracketed ${ }^{14} \mathrm{C}$ dates; for the pollen features, one third of the dates correspond to the precise features as represented in Figure 2A, and the other two third were calculated by using bracketed dates. 


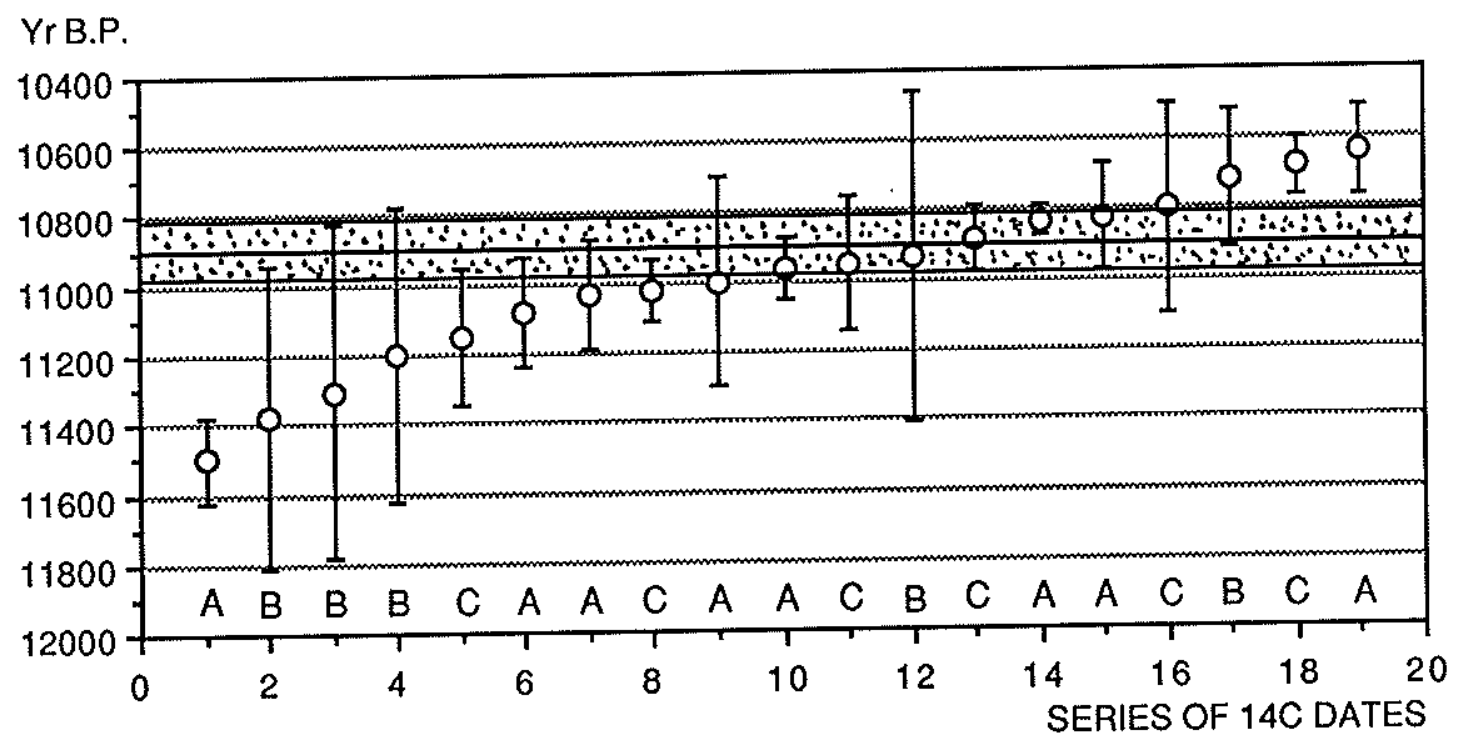

Juvigue et al Fig 1. 


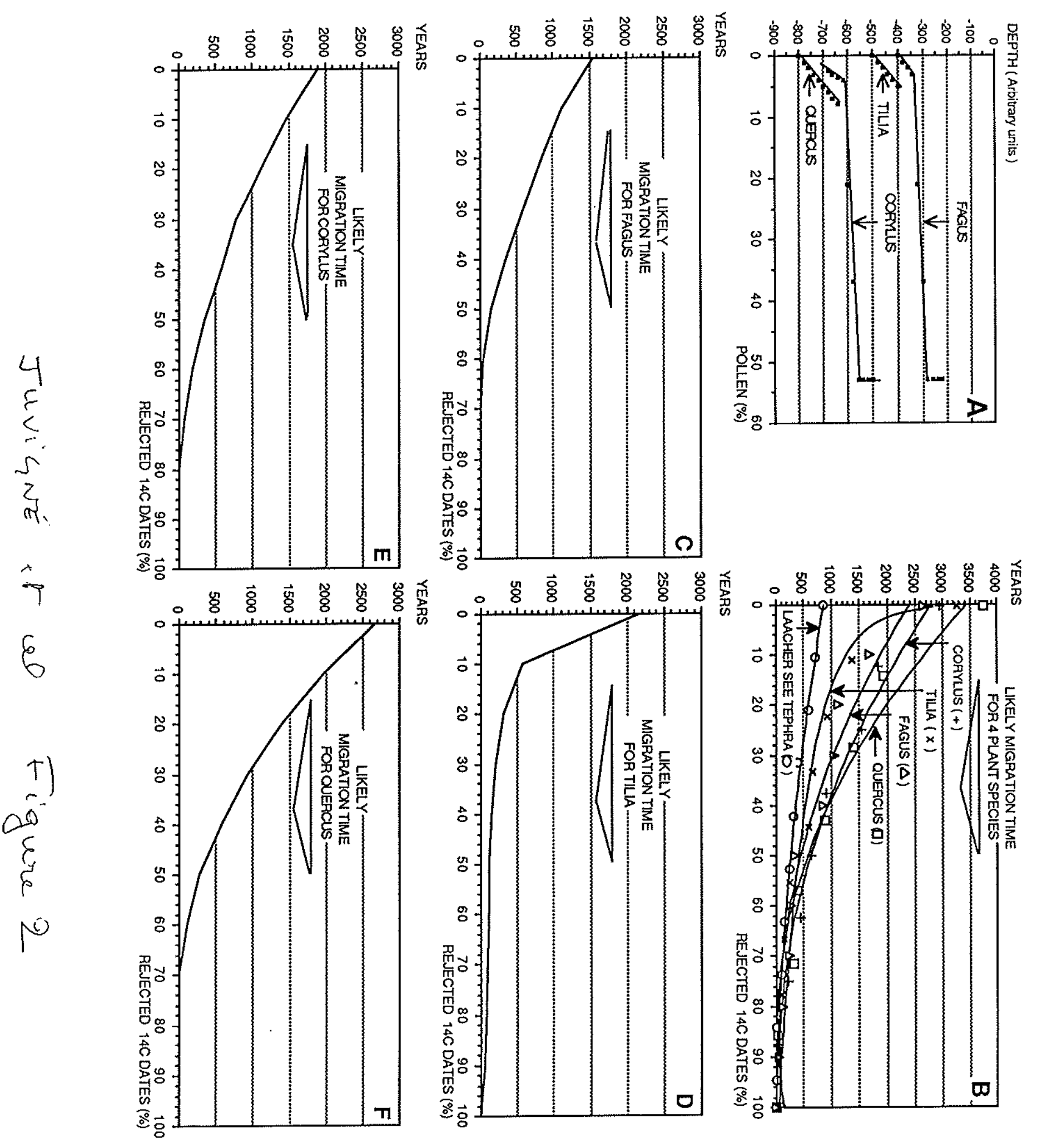




\begin{tabular}{|c|c|c|c|c|c|c|}
\hline & A & B & C & D & E & F \\
\hline 1 & Beaulieu et al., 1985 & Chaumette & 4300 & 180 & Ly 2110 & \\
\hline 2 & & & 4670 & 190 & Ly 2111 & \\
\hline 3 & & & 6880 & 200 & Ly 2112 & \\
\hline 4 & & & 7980 & 260 & Ly 2113 & \\
\hline 5 & & & 10430 & 570 & Ly 2114 & \\
\hline 6 & & & 10910 & 360 & Ly 1857 & \\
\hline 7 & & & 12370 & 340 & Ly 1858 & \\
\hline 8 & & & 11490 & 170 & Ly 2115 & Rejected \\
\hline 9 & & & 12810 & 250 & Ly 2116 & \\
\hline
\end{tabular}

Juvigné et al. Tab. 1 


\begin{tabular}{|c|c|c|c|c|c|c|c|c|c|c|c|c|c|c|c|c|c|c|c|c|c|c|}
\hline & $r$ & 015 & 0 & $\begin{array}{l}P^{2} \\
C\end{array}$ & 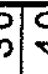 & & & 51 & & & & & & & & & & & & & & $0^{\circ}$ \\
\hline כ & $\infty$ & 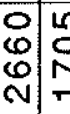 & 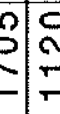 & $=$ & ?े: & ) & & $\hat{b}$ & & 8 & & & & & & & & & & & & 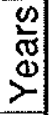 \\
\hline $\begin{array}{l}\sigma \\
\varangle\end{array}$ & $\propto$ & \begin{tabular}{l|l}
0 \\
\hdashline \\
\hdashline
\end{tabular} & $\frac{\infty}{m} \mid c$ & ז' & $\sqrt{7}$ & & & 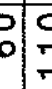 & 8 & $\frac{0}{7}$ & $a_{0}^{a}$ & 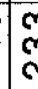 & & & & & $\stackrel{n}{\sigma}$ & $\begin{array}{l}0 \\
\infty \\
-\infty\end{array}$ & & 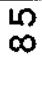 & 옹 & एं \\
\hline & $\sigma$ & \begin{tabular}{l|l}
0 & \multicolumn{1}{c}{} \\
& $\alpha$ \\
0 & $\alpha$ \\
0 & \multicolumn{1}{c}{}
\end{tabular} & 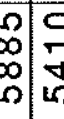 & 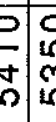 & 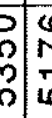 & $\frac{0}{2}$ & & \begin{tabular}{l|l}
8 \\
0 \\
0
\end{tabular} & 3 & $\stackrel{8}{0}$ & 5 & & & & & & $\begin{array}{c}n \\
m \\
\sigma\end{array}$ & $\begin{array}{l}8 \\
0 \\
0 \\
\text { o } \\
\text { a }\end{array}$ & & $\begin{array}{l}0 \\
\infty \\
\frac{1}{4}\end{array}$ & $\begin{array}{l}0 \\
0 \\
0 \\
\forall\end{array}$ & $\begin{array}{c}0 \\
\infty \\
\frac{1}{2}\end{array}$ \\
\hline & 0 & T: & $=\pi$ & 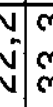 & : & $\begin{array}{l}f^{2} \\
+8\end{array}$ & ? & $\begin{array}{r}1 \\
0 \\
0\end{array}$ & $=\left[\begin{array}{l}\infty \\
\infty \\
\infty\end{array}\right.$ & & & & & & & & & & & & & مొ \\
\hline & 0 & 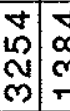 & \begin{tabular}{l|l}
$\dot{y}$ \\
0 \\
$m$ \\
\hdashline
\end{tabular} & $\begin{array}{l}8 \\
\vdots \\
3\end{array}$ & \begin{tabular}{l|l}
0 & 0 \\
0 & 1
\end{tabular} & $\begin{array}{lll}0 \\
0\end{array}$ & & $\frac{1}{0}$ & & & & & & & & & & & & & & $\begin{array}{l}0 \\
0 \\
0 \\
0 \\
0\end{array}$ \\
\hline E & $\mathbf{z}$ & & 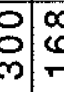 & \begin{tabular}{l|l}
0 \\
0
\end{tabular} & $\begin{array}{lll}0 \\
+\end{array}$ & s) & 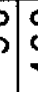 & \begin{tabular}{l|l}
0 \\
0 \\
0
\end{tabular} & | & 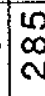 & 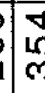 & 4 & & & $\begin{array}{c}n \\
\text { na }\end{array}$ & 5 & $\begin{array}{l}N \\
0 \\
m\end{array}$ & 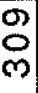 & 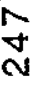 & & & نे \\
\hline & $\Sigma$ & \begin{tabular}{l|l}
\multicolumn{1}{c}{} \\
$\frac{1}{2}$ \\
\end{tabular} & 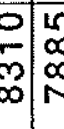 & \begin{tabular}{l|l}
8 & 0 \\
0 & 1 \\
0 & 1
\end{tabular} & \begin{tabular}{c|c}
5 \\
0 \\
0
\end{tabular} & 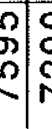 & & 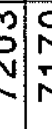 & $\sqrt{1}$ & O & 10 & , & & & & | & $\begin{array}{l}n \\
5 \\
5 \\
6 \\
0\end{array}$ & $\begin{array}{l}0 \\
N \\
\\
\omega \\
0\end{array}$ & & & & $\mid \begin{array}{l}0 \\
\infty \\
\frac{1}{2}\end{array}$ \\
\hline$\omega$ & - & 01 & 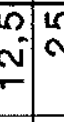 & $\stackrel{n}{n}$ & \begin{tabular}{c|c}
0 \\
\\
5
\end{tabular} & & & $\begin{array}{l}n \\
1 \\
0\end{array}$ & & & & & & & & & & & & & & $0^{\circ}$ \\
\hline$\stackrel{\sqsupset}{\vec{J}}$ & 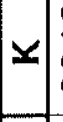 & 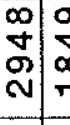 & 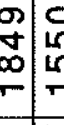 & 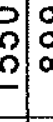 & S & : & t & $\frac{\mathbf{v}}{\mathrm{N}}$ & & & & & & & & & & & & & & 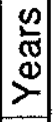 \\
\hline$\frac{1}{0}$ & $\checkmark$ & $\begin{array}{ccc}n & 6 \\
& 6\end{array}$ & $\begin{array}{c}0 \\
6 \\
6\end{array}$ & $\begin{array}{lll}5 \\
8\end{array}$ & $\begin{array}{c}\frac{0}{0} \\
\\
\end{array}$ & 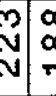 & : & $\begin{array}{c}5 \\
\end{array}$ & 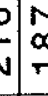 & $\stackrel{m}{N}$ & $\stackrel{1}{\alpha}$ & 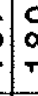 & & & & $\begin{array}{l}0 \\
9 \\
-2\end{array}$ & $\begin{array}{c}\infty \\
N \\
N\end{array}$ & & & & & $\begin{array}{l}u \\
c\end{array}$ \\
\hline 0 & - & 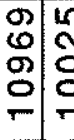 & 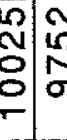 & \begin{tabular}{c|c}
$N$ & 0 \\
$c$ & 0 \\
$D$ & 8
\end{tabular} & : & 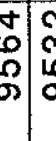 & & 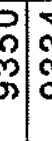 & & $\frac{\infty}{\sigma}$ & 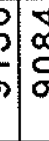 & $\begin{array}{l}c \\
0 \\
0 \\
0\end{array}$ & & & & 常 & $\bar{N}$ & & & & & $\begin{array}{l}0 \\
\dot{0} \\
\bar{\nu}\end{array}$ \\
\hline & $I$ & 0 & 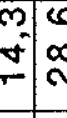 & $\begin{array}{l}0 \\
\\
\end{array}$ & $\begin{array}{l}n \\
\text { a } \\
\end{array}$ & 5 & & مी & & & & & & & & & & & & & & ○ீ \\
\hline $\overrightarrow{0}$ & ৫ & 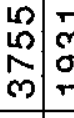 & 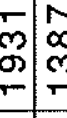 & $\begin{array}{lll}0 & 0 \\
0 & 0 \\
0\end{array}$ & $\begin{array}{c}n \\
\text { and } \\
0\end{array}$ & \begin{tabular}{cll}
5 \\
5 \\
\hdashline
\end{tabular} & & & & & & & & & & & & & & & & 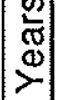 \\
\hline & 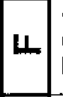 & $\stackrel{-i}{N}$ & $\begin{array}{lll}0 & \\
1 \\
n\end{array}$ & ${ }_{0}^{\circ}$ & S: & $\begin{array}{lll}2 & 0 \\
& ?\end{array}$ & $=$ & 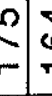 & ¿ & $\Omega$ & $\hat{s}$ & & & & $\begin{array}{l}8 \\
0 \\
\end{array}$ & & & & & & & एu \\
\hline o & 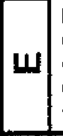 & 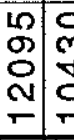 & \begin{tabular}{lll}
0 & 1 \\
0 \\
0 \\
0 \\
\hdashline
\end{tabular} & 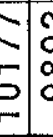 & ס: & \begin{tabular}{c|c}
$\infty$ \\
$\infty$ \\
$\infty$
\end{tabular} & & 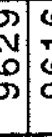 & & $\mid \begin{array}{l}0 \\
0 \\
\sigma \\
\sigma\end{array}$ & : & 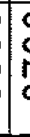 & & & $\begin{array}{l}0 \\
f \\
0 \\
0 \\
0\end{array}$ & & & & & & & $\begin{array}{l}a \\
\infty \\
\vdots \\
\vdots\end{array}$ \\
\hline 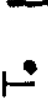 & 이 & 0 & 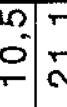 & 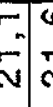 & $\frac{0}{n}$ & 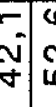 & & \begin{tabular}{l|l}
$n$ & 1 \\
0 & 0 \\
0 & 5
\end{tabular} & is & 8 & & & & & & & & & & & & ஃ \\
\hline 山 & 0 & \begin{tabular}{l|l}
0 & \multicolumn{1}{c}{} \\
0 & \\
$\infty$ & 1
\end{tabular} & \begin{tabular}{l|l}
$\circ$ & \multicolumn{1}{c}{} \\
0 & 0 \\
\end{tabular} & $\begin{array}{c}5 \\
\text { S. }\end{array}$ & s. & 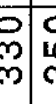 & & ? & & 10 & & & & & & & & & & & & 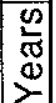 \\
\hline$\frac{\text { 岌 }}{\text { U }}$ & m & $\begin{array}{ll}\stackrel{L}{N} \\
\stackrel{L}{N}\end{array}$ & 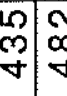 & $\begin{array}{lll} & 5 \\
0 & 5 \\
& 5\end{array}$ & $\begin{array}{l}N \\
\text { val }\end{array}$ & $\begin{array}{c}8 \\
0 \\
2\end{array}$ & $\Omega$ & 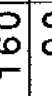 & 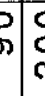 & O & ? & ? & & & & & & o & & 15 & & $\begin{array}{l}u \\
\dot{\infty}\end{array}$ \\
\hline$\frac{8}{4}$ & $\varangle$ & 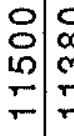 & 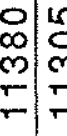 & $\begin{array}{ll}\Omega \\
0 \\
2\end{array}$ & $\begin{array}{c}0 \\
c \\
c\end{array}$ & $=$ & c. & 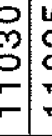 & ? & {$\left[\begin{array}{l}c \\
c \\
0 \\
0 \\
c\end{array}\right.$} & 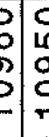 & & & $\begin{array}{l}0 \\
0 \\
0\end{array}$ & $\begin{array}{l}0 \\
\text { 足 } \\
0\end{array}$ & $\begin{array}{c}0 \\
\stackrel{\infty}{\infty} \\
0 \\
0\end{array}$ & $\begin{array}{l}8 \\
8 \\
0 \\
0 \\
0\end{array}$ & 今o & $\begin{array}{l}0 \\
\infty \\
0 \\
0 \\
0\end{array}$ & $\begin{array}{l}0 \\
0 \\
0 \\
0 \\
-\end{array}$ & & $\begin{array}{l}0 \\
0 \\
\vdots\end{array}$ \\
\hline & & & & & & & & & & & & & & 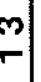 & $\begin{array}{l}+ \\
-\end{array}$ & 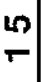 & $\stackrel{\omega}{\tau}$ & $\tau$ & $\frac{\infty}{-}$ & & & $\bar{v}$ \\
\hline
\end{tabular}

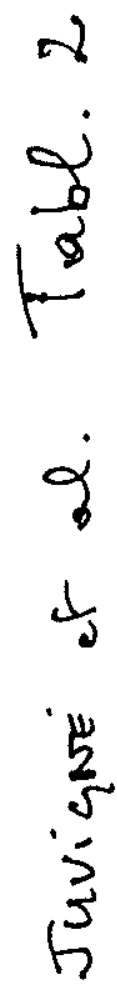

